\title{
Pollen Morphology and Its Relationship to the Taxonomy of the Genus Sarracenia (Sarraceniaceae)
}

\section{Citation}

Oswald, W. Wyatt, Elaine D. Doughty, G. Ne'eman, R. Ne'eman, and Aaron M. Ellison. Forthcoming. Pollen morphology and its relationship to taxonomy in the genus Sarracenia (Sarraceniaceae). Rhodora 113.

\section{Permanent link}

http://nrs.harvard.edu/urn-3:HUL.InstRepos:4731540

\section{Terms of Use}

This article was downloaded from Harvard University's DASH repository, and is made available under the terms and conditions applicable to Open Access Policy Articles, as set forth at http:// nrs.harvard.edu/urn-3:HUL.InstRepos:dash.current.terms-of-use\#OAP

\section{Share Your Story}

The Harvard community has made this article openly available. Please share how this access benefits you. Submit a story. 


\title{
Pollen morphology and its relationship to taxonomy of the genus Sarracenia (Sarraceniaceae)
}

\author{
W. W. Oswald ${ }^{1,2}$, E. D. Doughty ${ }^{2}$, G. Ne'eman ${ }^{3}$, R. Ne'eman ${ }^{4}$, and A. M. Ellison ${ }^{2}$ \\ ${ }^{1}$ Science Program, Department of Communication Sciences and Disorders, Emerson College, \\ Boston, MA 02116 \\ ${ }^{2}$ Harvard Forest, Harvard University, 324 North Main Street, Petersham, MA 01366 \\ ${ }^{3}$ Department of Science Education-Biology, Faculty of Science and Science Education, \\ University of Haifa-Oranim, Tivon 26006, Israel \\ ${ }^{4}$ Anne Frank High School, Branco Weiss Institute, Kibbutz Sasa 13870, Israel \\ Author for correspondence: W. Wyatt Oswald; email: w_wyatt_oswald@emerson.edu.
}


ABSTRACT. Despite nearly a century of research, the systematic relationships among North American pitcher plants in the genus Sarracenia (Sarraceniaceae) remain unresolved. In this study we analyzed pollen morphology of the 11 currently recognized species of Sarracenia and examined how variations in key pollen characteristics relate to our current understanding of the taxonomy of this genus. We used principal components analysis to explore variations in pollen grain size (equatorial diameter and length) and shape (number of colpi) among Sarracenia species, and used cluster analysis to compare systematic groupings of Sarracenia based on floral, vegetative, and pollen characters. We compared these results with a previously published phylogeny based on molecular data. Groupings based on pollen characteristics alone did not align completely with those based on molecular or all morphological data. In clusters based on pollen alone and those using all morphological characters, S. purpurea and S. rosea formed a single group, and S. flava, S. alata, and S. leucophylla grouped together consistently. The pollen morphology of S. jonesii and S. alabamensis differed substantially from that of S. rubra, supporting the current systematic treatment of the genus that recognizes these three taxa as distinct species.

Key Words: carnivorous plants; morphology; pollen; Sarracenia; systematics 
The ability to identify plants from their pollen has enabled botanists and ecologists to reconstruct past assemblages of plants and identify periods of environmental change (e.g., Faegri and Iversen 1989; Moore et al. 1991). Morphological characteristics of pollen grains also can be useful characters in studies of plant taxonomy because many pollen traits are influenced by the strong selective forces involved in various reproductive processes, including pollination, dispersal, and germination (e.g., Erdtman 1952; Moore et al. 1991; Nowicke and Skvarla 1979; Stuessy 1990). At the same time, characters subject to strong selection can be misleading if they reflect convergent evolution - similar evolutionary responses by unrelated taxa to similar environmental conditions. Thus, the use of pollen morphology as a taxonomic character is challenging and pollen characteristics must be considered in concert with other characteristics in evolutionary reconstructions.

In this study we document pollen characteristics of members of the genus Sarracenia (Sarraceniaceae) and examine how these characters relate to our current understanding of the systematics of these pitcher plants. Our study differs substantively from the only other survey of pollen morphology in Sarracenia (Thanikaimoni and Vasanthy 1974). Those authors were primarily interested in interfamilial and ordinal relationships, whereas we focus on discriminating species within the genus Sarracenia. Our work also reflects new systematic treatments (Mellichamp and Case 2009) and phylogenies based on allozymes and gene sequences (Bayer et al. 1996; Godt and Hamrick 1996; 1998; 1999; Neyland and Merchant 2006) that have been published since Thanikaimoni and Vasanthy did their work in the 1970s.

The genus Sarracenia. The 11 recognized species (Mellichamp and Case 2009) of pitcher plants in the genus Sarracenia L. are rosette-forming perennials with epiascidiate leaves 
that have been modified into pitcher-shaped traps (Adams and Smith 1977; Arber 1941) to which insects are attracted by nectar, odor, and/or color, and into which they fall, drown, and are digested (Bennett and Ellison 2009; Bhattarai and Horner 2009; Cresswell 1993; Green and Horner 2007; Macbride 1818; Schaefer and Ruxton 2008). All but one of the Sarracenia species are endemic to the southeastern United States (Godfrey and Wooten 1981). A recent phylogeny based on ITS-2 and 26S ribosomal RNA (Neyland and Merchant 2006) distinguishes three clades, two of which contain all but one of the species that are restricted to the Southeast (Fig. 1). One of these clades of southeastern species includes S. psittacina Michx., S. minor Walt., and S. flava L.; this clade was the only one identified by Neyland and Merchant (2006) that also received $>50 \%$ bootstrap support by Bayer et al. (1996). A second, larger clade includes S. alata Wood, S. leucophylla Raf., S. oreophila (Kearney) Wherry, and S. rubra Walt. sensu lato. Although neither Bayer et al. (1996) nor Neyland and Merchant (2006) supported the removal of S. jonesii Wherry and S. alabamensis (Case \& Case) Schnell as separate species from the S. rubra complex, both $S$. jonesii and S. alabamensis are recognized as distinct species in Flora of North America (Mellichamp and Case 2009). However, these two taxa (as S. rubra ssp.

alabamensis (Case \& Case) Schnell) and S. jonesii (as S. rubra ssp. jonesii (Wherry) Wherry) are listed, along with S. oreophila, as Endangered under the U.S. Endangered Species Act (U.S. Fish and Wildlife Service 1979; 1988; 1989). Thus, determining the distinctiveness of recognized taxa within the S. rubra complex has consequences for their legal conservation status.

The geographically widespread S. purpurea L., which occurs throughout the eastern United States and across Canada, is in a third clade (Fig. 1; Neyland and Merchant 2006). Two subspecies of S. purpurea are recognized by Mellichamp and Case (2009): S. purpurea L. ssp. purpurea and S. purpurea L. ssp. venosa (Raf.) Wherry. Sarracenia rosea Naczi, Case \& Case 
(formerly known as S. purpurea venosa var. burkii Schnell) also is in the S. purpurea clade, but is geographically isolated along the coast of the northern Gulf of Mexico (Schnell 1993).

Whereas Nichols (1908) noted only a close similarity among the pollen of S. flava, S. purpurea, S. rubra, S. psittacina, and S. variolaris Michx. (= S. minor), Thanikaimoni and Vasanthy (1974) found substantial variance in pollen-grain length, equatorial diameter, and numbers of colpi among these same species, plus S. alata and S. leucophylla. In this paper, we revisit the pollen morphology of these species, and expand the analysis to include $S$. rosea, $S$. oreophila, S. jonesii, and S. alabamensis. Thus, we present comparative pollen morphology of all currently recognized species of Sarracenia. We then examine whether or not variation in pollen morphology maps onto the hypothesized different clades of Sarracenia, and also if this variance can help shed light on the apparent infraspecific differentiation in S. purpurea and S. rubra.

\section{MATERIALS AND METHODS}

Pollen from all species except S. rosea was obtained from 10-yr-old greenhouse-grown

plants. These plants have been propagated at Harvard Forest from wild-collected seeds (S. flava, S. minor, S. leucophylla, S. alata, S. psittacina) or local populations (S. purpurea), from outcrossed seeds from cultivated plants (S. rubra, S. alabamensis, S. jonesii), or from vegetative divisions of cultivated plants (S. oreophila). In all cases the seeds were derived from single populations near the center of the range of each species; complete provenance data and germination methods are given in Ellison (2001). Because our S. rosea plants did not flower during this study, we obtained one mature flower of $S$. rosea from each of five plants in a single population in the Appalachicola National Forest in Florida. The S. rosea flowers were collected at the end of April 2009 directly into 70\% ethanol and shipped to Harvard Forest for pollen 
analysis. We note that our samples do not reflect the entire geographic range of each species and that intraspecific variability in pollen characters may be underestimated. However, if, as is widely assumed, pollen characters are subject to strong selection, then this underestimate is likely to be small.

Anthers of 15-20 Sarracenia flowers from each species, were pooled together, crushed with mortar and pestle, heated in $10 \% \mathrm{KOH}$, and processed with acetolysis; pollen residues were mounted in silicone oil (Faegri and Iversen 1989). Because we only had five flowers of S. rosea, we only used anthers from one of them and archived the others for future sampling, as needed. We measured 30 pollen grains from each species. For each grain, we measured length and equatorial diameter using image analysis software (Scion Image; Scion Corporation, Frederick, MD) and counted the number of colpi at $400 \times$ magnification. Post-hoc power analysis using the pwr library in R version 2.9 (R Development Core Team 2010) indicated that our sample size provided a very high probability (power approached 1) of correctly inferring significant differences among species (with a critical level $\alpha=0.05$ ), given the observed differences in length, equatorial diameter, and number of colpi.

Principal components analysis (function prcomp in R version 2.9) was used to create composite "size" and "shape" scores for each pollen grain. We then plotted the mean principal axis scores for each species along with their $95 \%$ confidence intervals to visualize separation or overlap in pollen morphology among the 11 Sarracenia species. To determine whether or not pollen characteristics provided additional discrimination among Sarracenia species, we compared systematic groupings obtained from cluster analysis (average linkage method in function helust of R version 2.9) of the species based on morphological characteristics other than pollen characters, and on a complete character matrix including vegetative, floral, and 
pollen characters (Table 1). Values for vegetative characters were collated from Mellichamp and Case (2009); whereas those for floral characters were taken from Naczi et al. (1999) and Schnell (1978). Because these sources generally report only averages and ranges, we used species' averages for pollen characters in the cluster analysis. Use of averages also avoided artificially inflating sample sizes and degrees of freedom.

Results of cluster analysis are reliable only when the number of variables (here, characters) does not exceed the number of observations (here, species). Because the number of measured characteristics greatly exceeded the number of species, we first summarized the vegetative characters in a series of principal component scores - one each for flower, seed, and pollen characters, and two each for pitcher and hood characters. The number of principal component scores used was based on the proportion of variance explained. In the case of flower, seed, and pollen characters, the first principal axis explained the majority of the variance, whereas for pitcher and hood characters, two principal axes were needed to account for most of the variance in the data. Rhizome diameter was included as a separate variable; it was first centered and scaled (observed mean - grand mean / standard deviation) so that its values were in the same range as the principal component scores (Table 2). Thus, the cluster analyses used either 7 variables (cluster analysis without pollen data) or 8 variables (cluster analysis with pollen data). We emphasize that the results of the cluster analyses do not provide information on phylogenetic relationships, as we have no information on character state polarity. Rather, the results of the cluster analysis simply illustrate groupings of species with similar morphological characters.

\section{RESULTS}


Sarracenia pollen grains are colpate, with the observed number of colpi ranging from 6 to 10. Equatorial diameter values ranged from 11.2 to $17.7 \mu \mathrm{m}$, and length ranged from 9.9 to 17 $\mu \mathrm{m}$ (Table 1). Principal components analysis revealed five distinct groupings of species (Fig. 2). Most taxa separated along the first principal axis, which reflects grain size (equatorial diameter and length) and accounted for $63 \%$ of the variance. Along this axis, the group including $S$. leucophylla, S. alata, and S. flava had very large grains (Table 1), whereas S. alabamensis, S. jonesii, and S. psittacina had the smallest grains (Table 1). Among the species with intermediatesized grains, S. purpurea and S. rosea formed one group, and S. rubra, S. minor, and S. oreophila formed the other. The second principal axis accounted for an additional $25 \%$ of the variance and separated taxa primarily on the number of colpi. On this axis, S. psittacina was separated out from the rest of the "small-grain" group because it has an unusually large number of colpi given its small grain size. For the remaining taxa, the number of colpi increased with grain size.

Cluster analysis of the morphological data (Table 2) without including the pollen characteristics identified four groups: the first included S. flava, S. alata, S. leucophylla, and S. oreophila; the second included S. purpurea and S. rosea; the third included S. rubra, S. alabamensis, and S. jonesii; and the fourth included S. minor and S. psittacina (Fig. 3A). Because several of the other (composite) morphological variables were significantly correlated with pollen size (Table 3), the cluster analysis that included the pollen characteristics did not change the identity of groupings, although it did increase the branch distances by approximately $10 \%$ (Fig. 3B). That is, the clusters were more clearly defined once pollen characteristics were included. Note that both dendrograms shown in Fig. 3 have terminal clusters that differ from the groupings identified on the basis of pollen alone (Fig. 2). Salient differences in the PCA-based clusters based on pollen alone (Fig. 2) included the separation of S. jonesii and S. alabamensis 
from S. rubra, the grouping of S. oreophila and S. minor with S. rubra, and the separation of $S$. psittacina from all other taxa. However, in both the clusters based on pollen alone (Fig. 2) and those using all morphological characters (Fig. 3), S. purpurea and S. rosea formed a single group, and S. flava, S. alata, and S. leucophylla consistently grouped together.

\section{DISCUSSION}

The genus Sarracenia has only a small number of species, but the pronounced intraspecific variability and common interspecific hybridization in this genus (Mellichamp and Case 2009) continue to puzzle taxonomists and phylogeneticists and suggest that Sarracenia has diversified very recently (Bayer et al. 1996; Godt and Hamrick 1998; Neyland and Merchant 2006; Romeo et al. 1977; Schnell and Krider 1976). Although morphological differences among named species can be quite spectacular (Schnell 2002), molecular analysis has found that fewer than 10 nucleotide substitutions separate species within distinguishable clades consisting of dramatically different taxa (e.g., $<10$ pair-wise differences in nucleotides among the tall greenpitchered S. flava, the hooded pitcher-plant S. minor, and the recumbent parrot pitcher-plant $S$. psittacina; Neyland and Merchant 2006). Our study of the morphology of pitcher-plant pollen illustrates both the strengths and limitations of pollen characteristics in helping to separate species within well-defined genera or clades, and so it is perhaps not surprising that morphological characteristics of pitcher-plant pollen are not always congruent with either molecular or morphological traits used to distinguish among Sarracenia species.

Our groupings of Sarracenia species based on pollen grain size and shape (Fig. 2) do not map precisely onto clades based on sequence data (compare Figs. 1 and 3). For example, $S$.

flava, S. leucophylla, and S. alata pollen grains group together based on their relatively large size 
and many colpi (Fig. 2), but molecular analyses place $S$. flava in a group with $S$. minor and $S$. psittacina, and groups S. alata and S. leucophylla together with S. oreophila and S. rubra (Fig. 1; Neyland and Merchant 2006). Pollen morphology also fails to align perfectly with groupings of Sarracenia species based on other morphological characteristics (compare Figs. 2 and 3).

Our data overlap to some extent with the measurements reported by Thanikaimoni and Vasanthy (1974). The number of colpi, for example, was similar for some species: S. minor had a mean of 7.9 in our study versus 7.97 in Thanikaimoni and Vasanthy (1974), and for S. rubra the mean values were 7.53 and 7.64 , respectively. On the other hand, the similarity was less for other species, including S. leucophylla (mean of 9.07 in our study, 7.71 in Thanikaimoni and Vasanthy 1974), S. flava (8.63 versus 7.02), S. alata (8.7 versus 7.06), and S. psittacina (8.77 versus 6.45). Discrepancies in size and shape could reflect intraspecific variation in pollen characters or differences in live versus dried material. We sampled from a single population of each species whereas Thanikaimoni and Vasanthy (1974) sampled either single cultivated plants or took pollen from herbarium sheets. In both cases, the samples in these two studies are of different provenance.

The identification of infraspecific taxa, both subspecies and varieties, adds further confusion to systematic treatments of Sarracenia. The differentiation and distinctiveness of the named subspecies and varieties of S. rubra and $S$. purpurea remains the most uncertain aspect of Sarracenia systematics (Case and Case 1974; 1976; Godt and Hamrick 1998; McDaniel 1966; 1971; Mellichamp and Case 2009; Neyland and Merchant 2006; Schnell 1977; 1979; Schnell and Krider 1976; Wherry 1929; 1933). Earlier treatments based on morphology suggested sufficient differences for establishing S. jonesii and S. alabamensis as unique species (Case and Case 1974; Wherry 1929); these distinctions have been upheld in the recent Flora of North America 
(Mellichamp and Case 2009). In contrast, the U.S. Fish and Wildlife Service used their designation as subspecies of S. rubra when they were listed as federally endangered taxa (U.S. Fish and Wildlife Service 1988; 1989).

Although allozyme data (Godt and Hamrick 1998) and sequence data (Bayer et al. 1996; Neyland and Merchant 2006) provided scant evidence for separating these taxa or any of the other named varieties from S. rubra sensu stricto, pollen morphology supports the most recent systematic treatment of this genus (Mellichamp and Case 2009). These taxa differ significantly in pollen-grain size: the pollen of S. rubra is larger (mean length of $13.24 \mu \mathrm{m}$, diameter of 15.46 $\mu \mathrm{m}$ ) than that of both $S$. jonesii and $S$. alabamensis (length of $\sim 12 \mu \mathrm{m}$, diameter of $\sim 14 \mu \mathrm{m}$ ). On the other hand, pollen morphology of S. purpurea and S. rosea is much more similar (Table 1, Fig. 3) than are other observed differences in morphology (Table 1; Naczi et al. 1999), germination (Ellison 2001), flavonoids (Romeo et al. 1977), allozymes (Godt and Hamrick 1998), and ribosomal RNA sequences (Neyland and Merchant 2006) that have been used to separate these species.

Overall, our results suggest that variations in key traits of pitcher plants that are associated with nutrient acquisition and reproduction—including the morphology of pitchers, flowers, pollen grains, and seed size, shape, and germination—are determined by complex interactions among various selective pressures. For example, germination requirements appear to be controlled by local environmental conditions (Ellison 2001), and pitcher morphology traits are influenced by the abundance of different prey groups (reviews in Ellison and Gotelli 2001; 2009). In contrast, variations in reproductive traits, such as floral and pollen morphology, more likely are determined by geographic isolation (e.g., Furness and Rudall 2004; Naczi et al. 1999). 
Further work on the systematics and phylogeny of the genus Sarracenia would be best served with a combined analysis of all available and reliable morphological and molecular data.

ACKNOWLEDGMENTS. We thank Tom Miller for collecting flowers of S. rosea, and the librarians at Harvard's Herbaria and Museum of Comparative Zoology for tracking down hard-to-find references on carnivorous plant pollen. This research was supported by NSF grant 02-35128 to A.M.E, a Charles Bullard Fellowship to G.N., and sabbatical leaves to G.N. and R.N. 


\section{Literature Cited}

Adams, R. M., II, and G. W. Smith. 1977. An S.E.M. survey of the five carnivorous pitcher plant genera. Am. J. Bot. 64: 265-272.

Arber, A. 1941. On the morphology of the pitcher-leaves in Heliamphora, Sarracenia, Darlingtonia, Cephalotus, and Nephenthes. Ann. Bot. 5: 563-578.

Bayer, R. J., L. Hufford, and D. E. Soltis. 1996. Phylogenetic relationships in Sarraceniaceae based on rbcL and ITS sequences. Syst Bot. 21: 121-134.

Bennett, K. F., and A. M. Ellison. 2009. Nectar, not colour, may lure insects to their death. Biol. Lett. 5: 469-472.

Bhattarai, G. P., and J. D. Horner. 2009. The importance of pitcher size in prey capture in the carnivorous plant, Sarracenia alata Wood (Sarraceniaceae). Am. Midl. Nat. 161: 264272.

Case, F.W., and R. B. Case. 1974. Sarracenia alabamensis, a newly recognized species from central Alabama. Rhodora 76: 650-665.

Case, F.W., and R. B. Case. 1976. The Sarracenia rubra complex. Rhodora 78: 270-325.

Cresswell, J. E. 1993. The morphological correlates of prey capture and resource parasitism in pitchers of the carnivorous plant Sarracenia purpurea. Am. Midl. Nat. 129: 35-41.

Ellison, A. M. 2001. Interspecific and intraspecific variation in seed size and germination requirements of Sarracenia (Sarraceniaceae). Am. J. Bot. 88: 429-437.

Ellison, A. M., and N. J. Gotelli. 2001. Evolutionary ecology of carnivorous plants. Trends Ecol. Evol. 16: 623-629.

Ellison, A. M., and N. J. Gotelli. 2009. Energetics and the evolution of carnivorous plants Darwin's 'most wonderful plants in the world'. J. Exp. Bot. 60: 19-42. 
Erdtman, G. 1952. Pollen morphology and plant taxonomy-Angiosperms. Almqvist and Wiksell, Stockholm, Sweden.

Faegri, K., and J. Iversen. 1989. Textbook of pollen analysis, Fourth edition. John Wiley and Sons, Chichester, UK.

Furness, C. A., and P. J. Rudall. 2004. Pollen aperture evolution - a crucial factor for eudicot success? Trends Plant Sci. 9: 154-158.

Godfrey, R. J., and J. W. Wooten. 1981. Aquatic and wetland plants of southeastern United States: dicotyledons. University of Georgia Press, Athens, Georgia, USA.

Godt, M. J. W., and J. L. Hamrick. 1996. Genetic structure of two endangered pitcher plants, Sarracenia jonesii and Sarracenia oreophila (Sarraceniaceae). Am. J. Bot. 83: 10161023.

Godt, M. J. W., and J. L. Hamrick. 1998. Allozyme diversity in the endangered pitcher plant Sarracenia rubra ssp. alabamensis (Sarraceniaceae) and its close relative S. rubra ssp. rubra. Am. J. Bot. 85: 802-810.

Godt, M. J. W., and J. L. Hamrick. 1999. Genetic divergence among infraspecific taxa of Sarracenia purpurea. Syst. Bot. 23: 427-438.

Green, M. L., and J. D. Horner. 2007. The relationship between prey capture and characteristics of the carnivorous pitcher plant, Sarracenia alata Wood. Am. Midl. Nat. 158: 424-431.

Macbride, J. 1818. On the power of Sarracenia adunca to entrap insects. Trans. Linn. Soc. 12: 48-52.

McDaniel, S. 1966. A taxonomic revision of Sarracenia (Sarraceniaceae). Ph.D. dissertation. Florida State University, Tallahassee, Florida, USA. 
McDaniel, S. 1971. The genus Sarracenia (Sarraceniaceae). Bull. Tall Timbers Res. Sta. 9: 136.

Mellichamp, T. L., and F. W. Case. 2009. Sarracenia. Flora of North America 8: 350-363.

Moore, P. D., J. A. Webb, and M. E. Collinson. 1991. Pollen analysis, Second edition. Blackwell Scientific Publications, Oxford, UK.

Naczi, R. F. C., E. M. Soper, F. W. Case, Jr., and R. B. Case. 1999. Sarracenia rosea (Sarraceniaceae), a new species of pitcher plant from the southeastern United States. Sida 18: 1183-1206.

Neyland, R., and M. Merchant. 2006. Systematic relationships of Sarraceniaceae inferred from nuclear ribosomal DNA sequences. Madroño 53: 223-232.

Nichols, M. L. 1908. The development of the pollen of Sarracenia. Botanical Gazette 45: 31-37.

Nowicke, J. W., and J. J. Skvarla. 1979. Pollen morphology: The potential influence in higher order systematics. Ann. Mo. Bot. Gard. 66: 633-700.

R Development Core Team. 2010. R: A language and environment for statistical computing, $\mathrm{R}$ Foundation for Statistical Computing, Vienna, Austria. http://www.r-project.org/..

Romeo, J. T., J. D. Bacon, and T. J. Mabry. 1977. Ecological considerations of amino acids and flavonoids in Sarracenia species. Biochem. Syst. Ecol. 5: 117-120.

Schaefer, H. M., and G. Ruxton. 2008. Fatal attraction-carnivorous plants roll out the red carpet to lure insects. Biol. Lett. 4: 153-155.

Schnell, D. E. 1977. Infraspecific variation in Sarracenia rubra Walt.: some observations. Castanea 42: 149-170.

Schnell, D. E. 1978. Systematic flower studies of Sarracenia L. Castanea 43: 211-220. 
Schnell, D. E. 1979. A critical review of published variants of Sarracenia purpurea L. Castanea 44: $47-59$.

Schnell, D. E. 1993. Sarracenia purpurea L. ssp. venosa (Raf.) Wherry var. burkii Schnell (Sarraceniaceae) — a new variety of the Gulf coastal plain. Rhodora 95: 6-10.

Schnell, D. E. 2002. Carnivorous plants of the Unites States and Canada, $2^{\text {nd }}$ edition. Timber Press, Portland, Oregon, USA.

Schnell, D. E., and D. W. Krider. 1976. Cluster analysis of the genus Sarracenia L. in the southeastern United States. Castanea 41: 165-176.

Stuessy, T. F. 1990. Plant taxonomy. Columbia University Press, New York, USA.

Thanikaimoni, G., and G. Vasanthy. 1974. Sarraceniaceae: palynology and systematics. Pollen et Spores 14: 143-155.

U.S. Fish and Wildlife Service. 1979. Determination that Sarracenia oreophila is an endangered species. Federal Register 44: 54922-54923.

U.S. Fish and Wildlife Service. 1988. Endangered and threatened wildlife and plants; determination of endangered status for Sarracenia rubra ssp. jonesii (Mountain Sweet Pitcher Plant). Federal Register 53: 38470-38474.

U.S. Fish and Wildlife Service. 1989. Endangered and threatened wildlife and plants: endangered status for Sarracenia rubra ssp. alabamensis. Federal Register 54: 10150-10154.

Wherry, E. T. 1929. Acidity relations of the Sarracenias. J. Wash. Acad. Sci. 19: 379-390.

Wherry, E. T. 1933. The geographic relations of Sarracenia purpurea. Bartonia 15: 1-6. 
Table 1. Morphological characteristics of currently recognized Sarracenia species. Data for vegetative characters are from

Mellichamp and Case (2009); those for flower characters are from Naczi et al. (1999) and Schnell (1978); and those for pollen characters are from this study. All measurements of continuous variables are in cm unless otherwise specified, and values for continuous variables are means as reported by the original authors.

\begin{tabular}{|c|c|c|c|c|c|c|c|c|c|c|c|}
\hline \multirow[b]{3}{*}{ Pitcher characters } & \multicolumn{11}{|c|}{ Sarracenia species } \\
\hline & alabamensis & alata & flava & jonesii & leucophylla & minor & oreophila & psittacina & purpurea & rosea & rubra \\
\hline & & & & & & & & & & & \\
\hline $\begin{array}{l}\text { Presence (1) or absence (0) of white } \\
\text { areolae on the pitcher }\end{array}$ & 0 & 0 & 0 & 0 & 1 & 1 & 0 & 1 & 0 & 0 & 0 \\
\hline Pitchers erect (0) or decumbent (1) & 0 & 0 & 0 & 0 & 0 & 0 & 0 & 1 & 1 & 1 & 0 \\
\hline $\begin{array}{l}\text { Phyllodia seasonally produced (1) or not } \\
\text { (0) }\end{array}$ & 1 & 0 & 1 & 0 & 1 & 0 & 1 & 0 & 0 & 0 & 0 \\
\hline Length of pitcher (to base of hood) & 40 & 45 & 52.5 & 47 & 62.5 & 28.5 & 46.5 & 19 & 15 & 17 & 31 \\
\hline Maximum width of pitcher wing & 0.9 & 1.5 & 0.75 & 0.6 & 1 & 2 & 0.75 & 2.5 & 2 & 2.8 & 1.25 \\
\hline Maximum diameter of pitcher opening & 3.7 & 3.5 & 4.5 & 2.5 & 4 & 2 & 3.25 & 0.75 & 2.5 & 3.5 & 2 \\
\hline Height of flower scape & 36 & 37.5 & 37.5 & 51 & 55 & 33.5 & 57.5 & 25 & 50.5 & 25.5 & 44.5 \\
\hline \multicolumn{12}{|l|}{ Hood characters } \\
\hline Length of hood & 4.9 & 4.75 & 6.5 & 4.45 & 4.5 & 3.6 & 5 & 3 & 3.5 & 4 & 2.6 \\
\hline Width of hood & 4.8 & 5 & 8.5 & 3.7 & 4 & 2.6 & 5.25 & 3 & 5 & 8 & 2.35 \\
\hline Width of neck of hood; 0 if absent & 1 & 0.75 & 2 & 0.75 & 1 & 0 & 1.5 & 0 & 0 & 0 & 0.5 \\
\hline Length of apiculum & 2 & 2 & 7.5 & 2.5 & 2.5 & 1 & 1.5 & 0 & 0 & 0 & 2 \\
\hline \multicolumn{12}{|l|}{ Rhizome character } \\
\hline Diameter of rhizome & 1 & 1.15 & 1.75 & 1 & 1.75 & 1.5 & 1.25 & 0.65 & 0.9 & 1.3 & 1 \\
\hline \multicolumn{12}{|l|}{ Floral characters } \\
\hline Total petal length & 3.4 & 5.6 & 7.7 & 3.5 & 5.1 & 4.5 & 4.7 & 3.8 & 4.4 & 4.9 & 3.1 \\
\hline Maximum width of the petal limb & 1.8 & 2.9 & 2.9 & 1.8 & 1.9 & 1.8 & 1.5 & 1.6 & 1.9 & 2.8 & 1.6 \\
\hline Width of the petal isthmus & 1 & 2.2 & 1.8 & 1.1 & 2.1 & 1.1 & 1.9 & 0.9 & 1.3 & 1.8 & 0.9 \\
\hline Maximum width of the petal base & 0.5 & 1.4 & 1.4 & 0.5 & 1.2 & 0.8 & 1 & 0.8 & 1 & 1.4 & 0.4 \\
\hline Length of the petal base & 1.1 & 2 & 2.5 & 1.2 & 2.1 & 1.5 & 2 & 1.2 & 1.5 & 2.1 & 1 \\
\hline Length of the petal limb & 2.3 & 3.6 & 5.2 & 2.3 & 3 & 3 & 2.7 & 2.6 & 2.9 & 2.8 & 2.1 \\
\hline
\end{tabular}


Bract length

Sepal length

Sepal diameter

Style diameter

Petal color ( 0 - yellow; 1 - pink; 2 - red)

Seed characters

Diameter of capsule

Length of seed (mm)

\begin{tabular}{rrrrrrrrrrr}
0.7 & 1.25 & 1.5 & 1.5 & 0.75 & 0.85 & 0.9 & 0.7 & 0.65 & 0.65 & 0.7 \\
2.5 & 4.5 & 4 & 3 & 4.25 & 2.5 & 4 & 2 & 3.2 & 3.85 & 2.1 \\
1.5 & 3.25 & 2.75 & 1.75 & 2.4 & 2.5 & 2.5 & 1.5 & 2.5 & 2.75 & 2.3 \\
3.25 & 6.5 & 7 & 3.25 & 6.5 & 3.5 & 6.75 & 2.5 & 4.5 & 6.1 & 2.75 \\
2 & 0 & 0 & 2 & 2 & 0 & 0 & 2 & 2 & 1 & 2 \\
& & & & & & & & & & \\
0.9 & 1.5 & 1.7 & 0.9 & 1.75 & 1.3 & 1.65 & 1 & 1.5 & 1.75 & 1 \\
1.35 & 2.1 & 2.15 & 1.35 & 1.8 & 1.2 & 1.9 & 1.75 & 1.85 & 2.05 & 1.35 \\
& & & & & & & & & & \\
14.15 & 15.51 & 16.18 & 13.75 & 15.65 & 14.84 & 15.17 & 13.88 & 14.22 & 14.35 & 15.46 \\
12.33 & 14.02 & 14.28 & 12.18 & 14.33 & 13.46 & 13.89 & 12.02 & 13.05 & 13.06 & 13.24 \\
7.17 & 8.7 & 8.63 & 7.13 & 9.07 & 7.9 & 8 & 8.77 & 7.97 & 8.1 & 7.53 \\
\hline
\end{tabular}

Equatorial diameter $(\mu \mathrm{m})$

Length $(\mu \mathrm{m})$

$\begin{array}{rrrr}12.33 & 14.02 & 14.28 & 12.18\end{array}$

9.07

8.77

$7.97 \quad 8.1$ 
Table 2. Principal axis scores of the multivariate data given in Table 1 and used in the cluster analyses. Because there was only one variable for rhizome (diameter), we did not subject it to PCA, but instead only scaled and centered it as described in text.

\begin{tabular}{|c|c|c|c|c|c|c|c|c|c|c|c|c|}
\hline \multirow[b]{2}{*}{$\begin{array}{l}\text { Principal axis (primary } \\
\text { characters loading) }\end{array}$} & \multirow[b]{2}{*}{$\begin{array}{l}\text { Variance } \\
\text { explained (\%) }\end{array}$} & \multicolumn{11}{|c|}{ Sarracenia species } \\
\hline & & alabamensis & alata & flava & jonesii & leucophylla & minor & oreophila & psittacina & purpurea & rosea & rubra \\
\hline Pitcher PC-1 (size) & 54 & -1.47 & -0.53 & -2.28 & -1.02 & -2.42 & 1.16 & -2.00 & 3.26 & 2.53 & 2.48 & 0.28 \\
\hline Pitcher PC-2 (colpi) & 18 & 0.12 & 0.25 & 0.18 & -0.53 & 0.83 & 1.60 & -0.94 & 1.69 & -2.64 & -0.09 & -0.48 \\
\hline Hood PC-1 (all characters) & 76 & -0.61 & -0.38 & -4.29 & -0.08 & -0.37 & 1.52 & -1.02 & 1.99 & 1.33 & 0.46 & 1.44 \\
\hline Hood PC-2 (length, width) & 18 & -0.11 & 0.09 & 0.00 & -0.57 & -0.58 & -0.41 & -0.10 & -0.11 & 0.77 & 2.07 & -1.06 \\
\hline Flower PC-1 (petals) & 71 & -3.06 & 3.75 & 4.69 & -2.20 & 1.41 & -0.76 & 1.22 & -3.01 & -0.64 & 1.93 & -3.33 \\
\hline Seed PC-1 (both characters) & 89 & -1.68 & 1.08 & 1.59 & -1.68 & 0.97 & -1.18 & 0.97 & -0.65 & 0.57 & 1.48 & -1.47 \\
\hline Pollen PC-1 (size) & 63 & -1.90 & 1.54 & 2.19 & -2.35 & 2.16 & 0.01 & 0.66 & -1.13 & -0.71 & -0.50 & 0.03 \\
\hline \multicolumn{13}{|l|}{ Standardized variable } \\
\hline Rhizome diameter & - & -0.59 & -0.16 & 1.56 & -0.59 & 1.56 & 0.85 & 0.13 & -1.59 & -0.87 & 0.27 & -0.59 \\
\hline
\end{tabular}


Table 3. Correlation matrix of principal axis scores and standardized rhizome diameter. Values shown in bold are significant at least at $P<0.05$

\begin{tabular}{rr} 
Pitcher PC-1 & \multicolumn{1}{l}{ Pitcher PC-2 } \\
0.00 & \\
$\mathbf{0 . 7 5}$ & 0.06 \\
0.48 & -0.26 \\
-0.57 & 0.24 \\
-0.35 & -0.02 \\
-0.11 & -0.17 \\
-0.44 & 0.16
\end{tabular}

Hood PC-1

0.00
$\mathbf{- 0 . 6 1}$
$\mathbf{- 0 . 6 8}$
-0.48
-0.50

Hood PC-2

-0.02
0.37
$\mathbf{0 . 5 6}$
-0.09

Rhizome

Flower PC-

Seed PC-1

Pitcher PC-2
Hood PC-1
Hood PC-2
Rhizome
Flower PC-1
Seed PC-1
Pollen PC-1 \\ Hood PC-1 \\ PC-2 \\ Seed PC-1}

Pollen $\mathrm{PC}-1$

0.16

$-0.48$

0.69

0.50
0.74

0.89

0.78 
Figure legends

Figure 1. Current phylogeny (unrooted) of Sarracenia, redrawn from Neyland and Merchant (2006).

Figure 2. Separation in principal component space of the 11 species of Sarracenia based on pollen morphology. For each species, we plot the average score $(N=30)$ for each principal axis along with its $95 \%$ confidence interval. The inset shows a pollen grain of S. oreophila with colpi (c) and location of diameter measurement (d) indicated. Grain length (I) was measured from pole to pole after rotating the pollen grain.

Figure 3. Dendrograms resulting from cluster analysis of the Sarracenia morphological data (Table 2) without (A) and with (B) the pollen characters included in the analysis. 


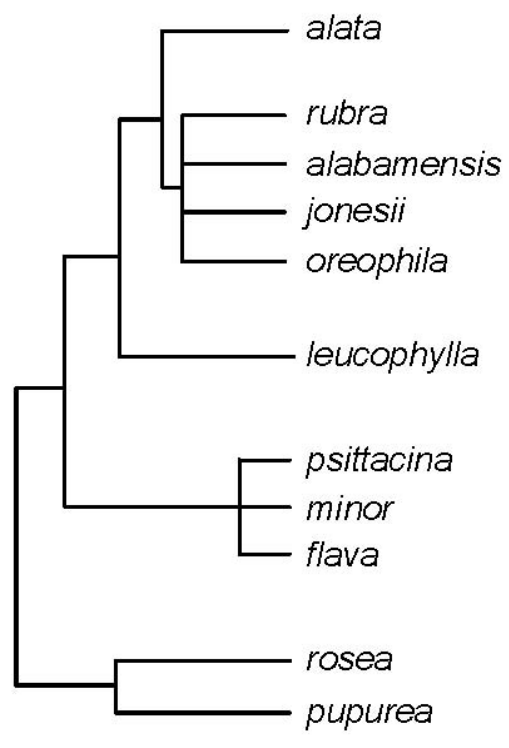

Figure 1 


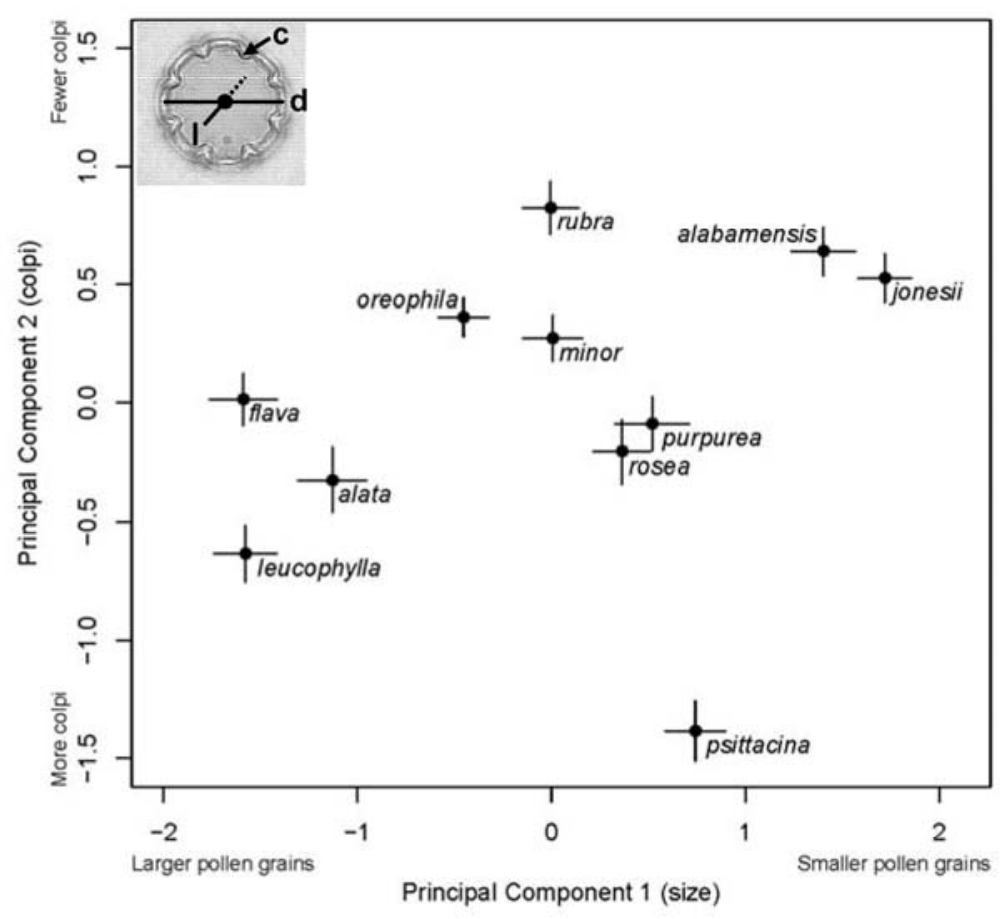

Figure 2 
A - Pollen data excluded

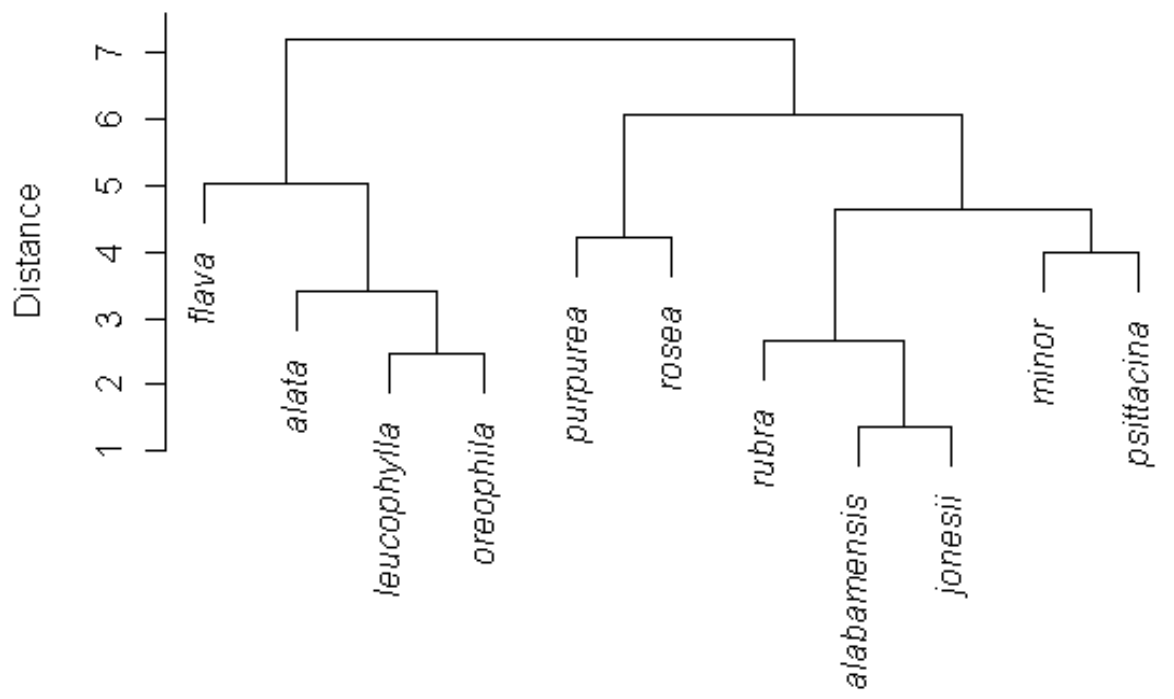

B - Pollen data included

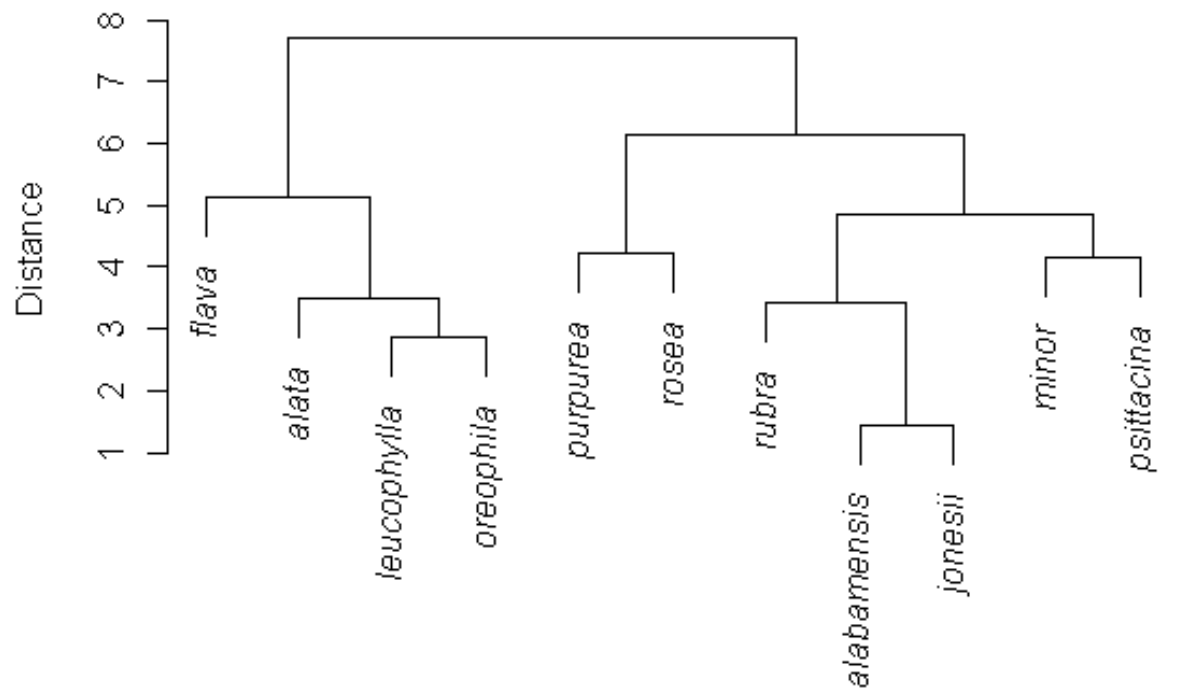

Figure 3 